\title{
A second look at leptin and adiponectin actions on the growth of primary porcine myoblasts under serum-free conditions
}

\author{
Katja Will', Judith Kuzinski', Marie-France Palin², Jan-Peter Hildebrandt ${ }^{3}$ and Charlotte \\ Rehfeldt ${ }^{1}$
}

'Institute for Muscle Biology and Growth, Leibniz Institute for Farm Animal Biology (FBN), Dummerstorf, Germany, ${ }^{2}$ Dairy \& Swine R \& D Centre, Agriculture and Agri-Food Canada, Sherbrooke, QC, Canada, ${ }^{3}$ Animal Physiology and Biochemistry, Zoological Institute, Ernst Moritz Arndt-University, Greifswald, Germany

\begin{abstract}
Cross-talk between adipose tissue and skeletal muscle may be mediated in part by adipokines. This study was conducted to elucidate further aspects of a possible role of recombinant adiponectin and leptin in the in vitro growth of primary porcine skeletal muscle cells cultured in energetically balanced, growth factor-supplemented, serum-free medium (GF-SFM). Therefore, the effects of these adipokines on cell number (DNA content), DNA synthesis rate, cell death and on key intracellular signalling molecules were investigated. Short-term adiponectin and leptin treatment decreased DNA synthesis, measured as $\left[{ }^{3} \mathrm{H}\right]-$ thymidine incorporation, as early as after 4 -h exposure $(P<0.01)$, without alterations in DNA content. Both adipokines attenuated the rate of cell death in terms of lactate dehydrogenase $(\mathrm{LDH})$ activity in the culture medium after $48-\mathrm{h}$ treatment $(P<0.05)$. The specific activation of p44/42 MAP kinase (MAPK) was reduced $(P<0.05)$ after 15 -min incubation with either adipokine. In conclusion, the early decreases in DNA synthesis of primary porcine myoblasts cultured in GF-SFM in response to adiponectin or leptin are related to p44/42 MAPK signalling and adipokine treatment does not impair cell viability.
\end{abstract}

Keywords: adiponectin, leptin, pig, satellite cell culture, signalling molecules

Archiv Tierzucht 57 (2014) 29, 1-10

doi: 10.7482/0003-9438-57-029

Corresponding author:

Charlotte Rehfeldt; email: rehfeldt@fbn-dummerstorf.de

Institute for Muscle Biology \& Growth, Leibniz Institute for Farm Animal Biology, Wilhelm-Stahl-Allee 2, 18196 Dummerstorf, Germany

(c) 2014 by the authors; licensee Leibniz Institute for Farm Animal Biology (FBN), Dummerstorf, Germany. This is an Open Access article distributed under the terms and conditions of the Creative Commons Attribution 3.0 License (http://creativecommons.org/licenses/by/3.0/).
Received: 5 March 2014

Accepted: 15 July 2014

Online: 29 October 2014 


\begin{abstract}
Abbreviations: Akt: protein kinase B; AMPK: AMP-activated protein kinase; bFGF: basic fibroblast growth factor; BSA:bovineserumalbumin;DNA:deoxyribonucleicacid;FBS:fetalbovineserum;GF-SFM:growthfactorsupplemented,serum-freemedium;GM:growthmedium;HS:horseserum;LDH:lactatedehydrogenase; MAPK: mitogen-activated protein kinase; MCDB 110: molecular, cellular, and developmental biology medium 110; MEMa: minimum essential medium a; mTOR: mammalian target of rapamycin; SDSPAGE: sodium dodecyl sulfate polyacrylamide gel electrophoresis; SM: semimembranosus
\end{abstract}

\title{
Introduction
}

Today, the view of adipose tissue as an active endocrine organ by its ability to secrete adipokines is well-established (Miner 2004, Hauner 2005, Gimeno \& Klaman 2005). Interactions of adipokines with skeletal muscle have been reported and are of scientific interest as this tissue plays a major role in regulating metabolic homeostasis (Bonen 2010). Furthermore, gaining detailed insight into the functional cross-talk between adipocytes and muscle cells is an important aim not only in animal science (Bonnet et al. 2010) but also in human medical research (Fruehbeck 2008). Until now, most of the investigations on adipokines, such as adiponectin and leptin, focused on their function in energy metabolism of several tissues and cell types (Brochu-Gaudreau et al. 2010, Moon et al. 2013).

Concerning adipokine-mediated regulation of intracellular signalling pathways, the AMPactivated protein kinase (AMPK) was shown to be activated by globular and full-length adiponectin treatment in skeletal muscle of rats and humans (Tomas et al. 2002, Tsao et al. 2003, Mullen et al. 2009). Besides AMPK, other kinases, such as protein kinase B (Akt), mammalian target of rapamycin (mTOR) and/or p44/42 mitogen-activated protein kinase (MAPK), known to be involved in growth-mediating intracellular signalling pathways, can be phosphorylated after adiponectin treatment of murine muscle cell lines (Yamauchi et al. 2001, Wang et al. 2007, Fiaschi et al. 2009, Fiaschi et al. 2010) or human embryonic kidney cells (Lee et al. 2008). Similarly, leptin was found to affect skeletal muscle growth of rodents and humans via activation of components of the insulin signalling pathway such as Akt and p44/42 MAPK (Maroni et al. 2005, Maroni et al. 2009) and by the stimulation of AMPK (Minokoshi et al. 2002). As adiponectin and leptin can stimulate antagonistic intracellular pathways, it is difficult to predict the effects of these adipokines on muscle cell growth. This becomes even clearer by looking at inconsistent results of a few studies, most of them performed using rodent muscle, reporting about stimulating (Lamosova and Zeman 2001, Ramsay 2003, Yu et al. 2008, Fiaschi et al. 2010), inhibitory (Arita et al. 2002, Wang et al. 2005) or a lack of effects (Carbo et al. 2000). As previously shown, long-term adiponectin and leptin treatment over 24 or $48 \mathrm{~h}$ appeared not to have direct effects on growth and protein metabolism of proliferating porcine myoblasts (Will et al. 2012). However, the presence of growth factors in cell culture medium was suggested to be an important factor for the adipokine effects, especially of adiponectin. To elucidate further aspects of adiponectin and leptin action on the growth of porcine skeletal muscle cells under serum-free culture conditions in growth factor-supplemented serum-free medium (GF-SFM), the effects of these adipokines on cell number (DNA content) and DNA synthesis rate after short-term treatment as well as on cell death and the activation of key signalling molecules involved in energy metabolism and cell growth were investigated. 


\section{Material and methods}

\section{Muscle cell culture}

The right and left semimembranosus (SM) muscles of newborn German Landrace piglets ( $n=34$ males) were taken to establish a pool from all cells isolated during several preparation procedures. To isolate myogenic cells, a Percoll gradient was used as described previously (Mau et al. 2008a). Thereafter, fluorescence analysis of an aliquot of cells immunostained for desmin resulted in $86 \%$ muscle satellite cells in the pool. The flow cytometry step was performed using an EPICS-Elite flow cytometer (Beckman Coulter, Krefeld, Germany) as described before (Mau et al. 2008a, Loehrke et al. 1998). Satellite cell-derived myoblast cultures were used.

The guidelines set by the Animal Care Committee of the State Mecklenburg-Western Pomerania, Germany, based on the German Law of Animal Protection were observed during animal husbandry and slaughter.

\section{Sources of adiponectin and leptin}

For this study, recombinant porcine adiponectin produced in E. coli was used (Ledoux et al. 2006). The detailed process of its obtaining was already described by Will et al. (2012) and its biological activity was shown in a former study by inducing periovulatory changes in ovarian follicular cells (Ledoux et al. 2006). Recombinant porcine leptin produced in E. coli was obtained from ProSpec (East Brunswick, NJ, USA). According to the manufacturer, porcine leptin was proved to be biologically active by causing proliferation of BA/F3 cells (murine bone marrow-derived pro-B cell line) stably transfected with the long form of human leptin receptor.

\section{Experiments on DNA synthesis rate}

For the experiments on DNA synthesis rate (Table 1), gelatin-coated (0.1\%) 96-well microplates were used. After cautious thawing, satellite cells were seeded at a density of about $5 \times 10^{3}$ cells per well and cultured for two days in minimum essential medium a (MEMa) and molecular, cellular and developmental biology medium 110 (MCDB 110; ratio 4:1) (Sigma-Aldrich) supplemented with $10 \%$ fetal bovine serum (FBS; Invitrogen, Karlsruhe, Germany) and $10 \%$ horse serum (HS; Sigma-Aldrich) plus glutamine (4 mM; Serva, Heidelberg, Germany) and antibiotics $(2.5 \mu \mathrm{g} / \mathrm{ml}$ amphotericin $\mathrm{B} ; 100 \mathrm{IU} / \mathrm{ml}$ penicillin; $100 \mu \mathrm{g} / \mathrm{ml}$ streptomycin; SigmaAldrich) as described in former studies (growth medium, GM; Will et al. 2012). On day 3, cells were incubated for $24 \mathrm{~h}$ with GF-SFM, a serum-free culture medium supplemented with insulin $(1 \mu \mathrm{M})$, basic fibroblast growth factor (bFGF; $10 \mathrm{ng} / \mathrm{ml})$, platelet-derived growth factor (PDGF-BB; $5 \mathrm{ng} / \mathrm{ml})$, bovine serum albumin (BSA; $0.5 \mathrm{mg} / \mathrm{ml})$, dexamethasone $(0.1 \mu \mathrm{M})$, linoleic acid $(0.5 \mu \mathrm{g} / \mathrm{ml})$ and transferrin $(100 \mu \mathrm{g} / \mathrm{ml})$ (Sigma-Aldrich or Invitrogen) according to Doumit et al. (1996) before being treated with adiponectin $(40 \mu \mathrm{g} / \mathrm{ml})$ or leptin $(20 \mathrm{ng} / \mathrm{ml})$ for $4 \mathrm{~h}$. Cells were labelled with $0.2 \mu \mathrm{Ci}\left[{ }^{3} \mathrm{H}\right]$-thymidine $(60-90 \mathrm{Ci} / \mathrm{mM}$, batch 123716 ; Hartmann Analytic, Braunschweig, Germany) during the entire period ( $4 \mathrm{~h}$ ) of treatment. As described previously (Rehfeldt \& Walther 1997, Will et al. 2012), DNA synthesis, as the incorporation of [ $\left.{ }^{3} \mathrm{H}\right]$-thymidine into cellular DNA, and DNA content could be measured in combined assays in monolayers. 
Table 1

Design of cell culture experiments on adipokine effects on cellular growth, signalling and cell viability of porcine myoblasts

\begin{tabular}{lccccl}
\hline Experiment & Time of cultivation (d) in & \multicolumn{3}{c}{ Treatment in GF-SFM } \\
& GM & GF-SFM & Duration (h) & $n$ & Treatment \\
\hline DNA synthesis & 2 & 1 & 4 & 10 & $40 \mu \mathrm{g} / \mathrm{ml}$ adiponectin, \\
Signalling molecules & 2 & 1 & $0.25,0.5$ & 3 & or $20 \mathrm{ng} / \mathrm{ml}$ leptin, \\
Cell viability & 2 & 0 & $10,24,48$ & 10 & or untreated control \\
\hline
\end{tabular}

GM: growth medium (MEMalpha:MCDB+10\% FBS+10\% HS), GF-SFM: growth factor-supplemented, serum-free medium

\section{Specific activation of key intracellular signalling molecules}

\section{Experiments}

For the investigation of the phosphorylation level of AMPKa, Akt, mTOR and p44/42 MAPK in proliferating myoblasts after short-term treatment with adiponectin or leptin (Table 1), satellite cells were seeded in gelatin-coated $(0.1 \%) 35 \mathrm{~mm}$ dishes at a density of $4 \times 10^{5}$ cells per dish. Cells were grown for two days in MEMa and MCDB 110 (ratio 4:1) plus $10 \%$ FBS and $10 \% \mathrm{HS}$ plus glutamine and antibiotics as described above. Thereafter, cells were grown in GF-SFM for $24 \mathrm{~h}$. On day 4 of the experiments, cells were treated with adipokines at the same concentrations used for experiments on DNA synthesis rate and cell viability $(20 \mathrm{ng} / \mathrm{ml}$ leptin, $40 \mu \mathrm{g} / \mathrm{ml}$ adiponectin) for 15 or $30 \mathrm{~min}$.

\section{Protein extraction, SDS-PAGE and Western Blot}

The total protein lysate of the cells was extracted and supernatants were collected as described previously (Will et al. 2012). After determining the protein content using a method described by Peterson (1977), aliquots were stored at $-80^{\circ} \mathrm{C}$ until further analysis. After thawing, the preparation of protein aliquots for sodium dodecyl sulfate polyacrylamide gel electrophoresis (SDS-PAGE) was performed as described previously (Will et al. 2012). Before being separated on $10 \%$ SDS-PAGE gels (2-3 h at $125 \mathrm{~V}$ ), fifty micrograms of protein samples contained in sample buffer $(125 \mathrm{mM}$ Tris- $\mathrm{HCl}, \mathrm{pH} 6.8,4 \% \mathrm{SDS}, 20 \%$ glycerol, $0.05 \%$ bromophenol blue, $10 \% \beta$-mercaptoethanol) were heated for $5 \mathrm{~min}$ at $95^{\circ} \mathrm{C}$. After electrophoresis, proteins were transferred to polyvinylidine fluoride (PVDF) membranes (GE Healthcare Europe $\mathrm{GmbH}$, Munich, Germany; $140 \mathrm{~mA}$ for 2 blots, $10 \mathrm{~V}, 1.5$ h). Coomassie blue staining of membranes was used to ensure the efficient protein transfer to the membranes. To verify equal loading of the gels, a tubulin was detected using a mouse monoclonal anti-a tubulin antibody (1:5000; T5168, Clone B-5-1-2, Sigma-Aldrich). After blocking of the membranes with a solution of $5 \%$ dry milk and Tris-buffered saline for $1 \mathrm{~h}$ at room temperature, the incubation with primary antibodies ( $5 \%$ dry milk and Tris-buffered saline with $0.1 \%$ Tween 20; TBST) was performed overnight at $4{ }^{\circ} \mathrm{C}$. The phosphorylation levels of AMPK (on Thr172, rabbit mAb no. 2535), Akt (on Ser473, rabbit mAb no. 4060), mTOR (on Ser2448, rabbit mAb no. 2971) and p44/42 MAPK (on Thr202/Tyr204, rabbit mAb no. 4370) were studied. With the exception of Akt and pAkt antibodies, which were used at dilutions of 1:2000 and 1:4000, respectively, all other antibodies were diluted as recommended by the manufacturer. Additionally, all membranes were incubated with antibodies specific for 
the core proteins (AMPKa no. 2603, Akt no. 9272, mTOR no. 2983, p44/42 MAPK no. 4695). All used antibodies were purchased from Cell Signaling Technology (New England Biolabs, Frankfurt, Germany). After treatment with the primary antibody, membranes were washed three times for $10 \mathrm{~min}$ in TBST followed by incubation with horseradish peroxidase (HRP)conjugated donkey anti-rabbit lgG (1:5000; sc-2313; Santa Cruz Biotechnology) or, for a tubulin with HRP-conjugated sheep anti-mouse IgG (1:10 000 or 1:25 000; NA931-100 $\mu$, GE Healthcare), for $1.5 \mathrm{~h}$ at room temperature. For the development of the membranes, the ECL Plus Western Blotting Detection System (RPN 2132; GE Healthcare) and a Chemocam HR-16 imager (INTAS, Göttingen, Germany) were used. The Lablmage 1D Software (Kapelan Bio-Imaging $\mathrm{GmbH}$, Leipzig, Germany) was utilized to quantify the intensities of the gained protein bands. According to Rehfeldt et al. (2010), signals derived from phosphospecific antibodies were normalized for the expression of their respective core protein to estimate the specific phosphorylation level of the investigated signalling molecules. The analyses were done in triplicates for each protein.

\section{Cell viability}

For the experiments on adipokine-mediated effects on cell viability (Table 1), satellite cells were cultured in GF-SFM in 96-well plates as described above. The rates of cell death were determined by measuring lactate dehydrogenase (LDH) activity in cell culture supernatants, as described previously (Mau et al. 2008b), after 10-, 24- and 48-h exposure to leptin (20 ng/ $\mathrm{ml})$ or adiponectin $(40 \mu \mathrm{g} / \mathrm{ml})$.

\section{Statistics}

Analysis of variance was performed using the GLM procedure of SAS (Version 9.2; SAS Institute Inc., Cary, NC, USA) with experiment, treatment and respective interactions and side of the plate as fixed factors for experiments on DNA synthesis rate and DNA content. The considered fixed factors for analysis of LDH activity were treatment and side of the plate. Treatment was the fixed factor for the analysis of the data on specific activation of signalling molecules. Values of $P<0.05$ and $0.05<P<0.10$ were considered to be statistically significant and as a tendency, respectively.

\section{Results}

Effects of adiponectin and leptin on DNA synthesis rate and cell viability of porcine skeletal muscle cultures

In addition to 24-h and 48-h exposure to the adipokines (Will et al. 2012), the effects of adiponectin or leptin were examined in proliferating porcine myoblast cultures after shortterm exposure ( $4 \mathrm{~h}$ ) in GF-SFM. Both the addition of adiponectin and leptin recombinant proteins led to a significant decrease of DNA synthesis rate (Figure 1A), while the DNA content remained unchanged (Figure 1B). The effects of adiponectin and leptin on cell viability were examined after 10-, 24-, and 48-h exposure in GF-SFM. Treatment of cells with adiponectin or leptin for $48 \mathrm{~h}$ decreased LDH activity to approximately $76 \%$ of the control value (Table 2) indicating that myoblast viability was somewhat increased by either adipokine. 


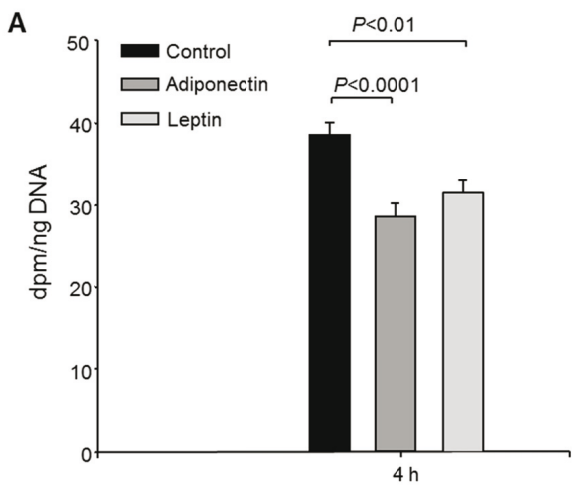

Time of incubation

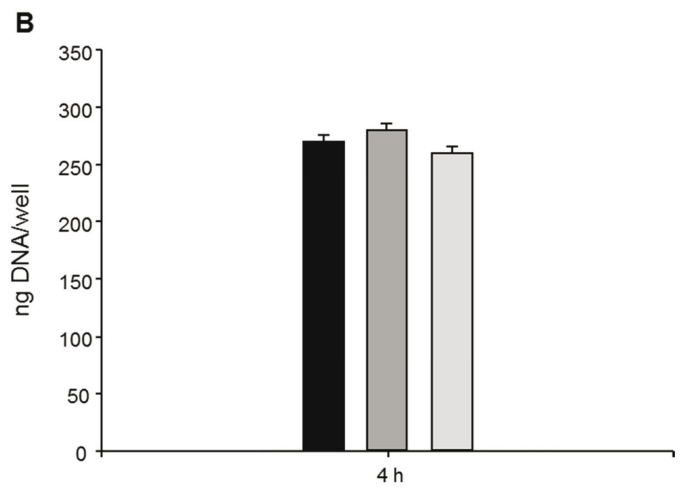

Time of incubation

Columns and error bars represent least squares means and SE of dpm/ng DNA and ng DNA/well. The number of observations per treatment and time point was $n=10$.

\section{Figure 1}

DNA synthesis rate (A) and DNA content (B) - taken as equivalent for cell number - of porcine myoblasts measured as incorporation of $\left.{ }^{3} \mathrm{H}\right]$-thymidine over $4 \mathrm{~h}$ in response to a $4-\mathrm{h}$ exposure to recombinant porcine adiponectin $(40 \mu \mathrm{g} / \mathrm{ml})$ or leptin $(20 \mathrm{ng} / \mathrm{ml})$ in growth factor-supplemented, serum-free culture medium

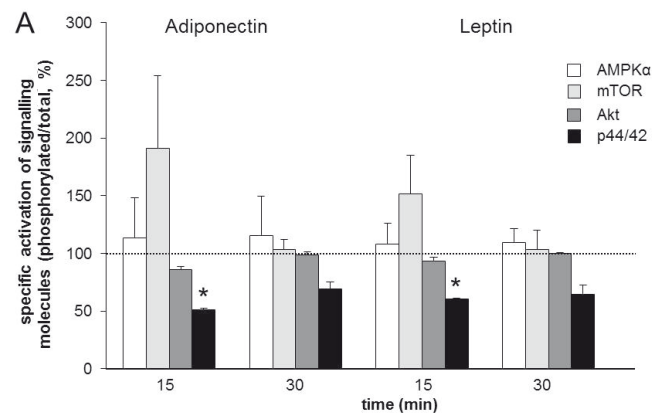

The number of observations per treatment and time point was $n=3$ for each protein. ${ }^{*} P<0.05$ vs. control set as $100 \%$. B: Typical Western Blot of the specific activation of AMPKa. Bands were detected at $\sim 65 \mathrm{kDa}$.

C: Typical Western Blot of the specific activation of Akt. Bands were detected at $\sim 60 \mathrm{kDa}$.

D: Typical Western Blot of the specific activation of mTOR. Bands were detected at $200 \mathrm{kDa}$ for pmTOR and mTOR, respectively.

E: Typical Western Blot of the specific activation of $p 44 / 42$ MAPK. Bands were detected at $\sim 44$ and $42 \mathrm{kDa}$ for pp44/42 MAPK and p44/42 MAPK, respectively

F: The detection of a tubulin ( $55 \mathrm{kDa}$, secondary antibody: 1:25 000) was used as loading control. Data are represented as means and SE.
B

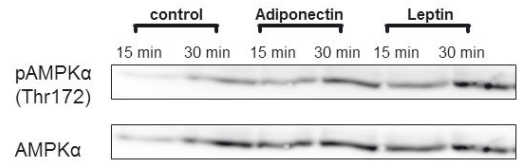

C

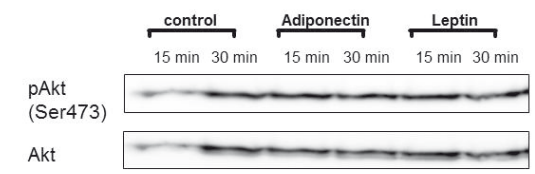

D
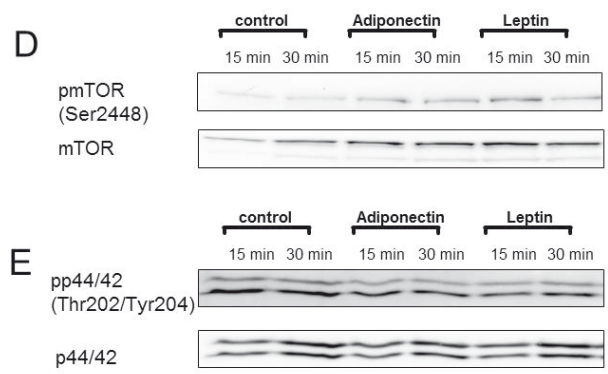

F a tubulin $\stackrel{\text { control }}{15 \mathrm{~min} 30 \mathrm{~min}} \stackrel{\text { Adiponectin }}{15 \mathrm{~min} 30 \mathrm{~min}} \stackrel{\text { Leptin }}{15 \mathrm{~min} 30 \mathrm{~min}}$

Figure 2

Activation of various intracellular signalling molecules in porcine myoblasts in untreated cultures (control) or after application of $40 \mu \mathrm{g} / \mathrm{ml}$ adiponectin or $20 \mathrm{ng} / \mathrm{ml} \mathrm{leptin}$ for 15 or $30 \mathrm{~min}$ in growth factor-supplemented, serum-free medium (A) 
Table 2

Lactate dehydrogenase (LDH) activity in supernatant as a measure for rates of cell death in proliferating porcine myoblast cultures after treatment with adiponectin $(40 \mu \mathrm{g} / \mathrm{ml})$ or leptin $(20 \mathrm{ng} / \mathrm{ml})$ for 10,24 or $48 \mathrm{~h}$ in growth factor-supplemented, serum-free medium

\begin{tabular}{llccc}
\hline & Treatment & \multicolumn{3}{c}{ Time of Exposure } \\
& & $10 \mathrm{~h}$ & $24 \mathrm{~h}$ & $48 \mathrm{~h}$ \\
\hline $\mathrm{LDH} / \mathrm{DNA}(\mathrm{mlU} / \mu \mathrm{g})$ & Control & $0.65 \pm 0.06$ & $0.46 \pm 0.06$ & $0.84 \pm 0.06^{\mathrm{a}}$ \\
$(\mathrm{n}=10)$ & Adiponectin & $0.66 \pm 0.06$ & $0.35 \pm 0.06$ & $0.67 \pm 0.06^{\mathrm{b}}$ \\
& Leptin & $0.64 \pm 0.06$ & $0.34 \pm 0.06$ & $0.64 \pm 0.06^{\mathrm{b}}$ \\
\hline
\end{tabular}

Data are represented as least squares means and SE. ${ }^{a b}$ LS Means within a column not sharing common letters significantly differ $(P<0.05)$.

\section{Specific activation of signalling molecules}

The effects of adiponectin or leptin on the phosphorylation or on their specific activation, respectively, of AMPK, Akt, mTOR and p44/42 MAPK were examined in proliferating porcine myoblast cultures after exposure times of 15 and $30 \mathrm{~min}$ (Figure 2). Adiponectin or leptin alone decreased the phosphorylation levels of p44/42 MAPK after 15-min (adiponectin: $-39.6 \% \pm 0.9 \%, P=0.03$; leptin: $-49.1 \% \pm 2.4 \% P=0.01$ ), but only numerically after 30 -min treatment. No significant changes in the phosphorylation levels of AMPK, Akt or mTOR after myoblast exposure to either adiponectin or leptin were observed compared with untreated controls after $15 \mathrm{~min}$ and $30 \mathrm{~min}$ (Figure 2).

\section{Discussion}

In addition to findings reported in our previous study (Will et al. 2012), it is shown here that short-term treatment of primary porcine skeletal muscle cells with adiponectin or leptin in GF-SFM led to diminished DNA synthesis rate, whereas DNA content remained unaffected. Furthermore, cell viability remained unchanged after $24-h$ and was increased by adiponectin and leptin treatment after 48-h exposure. We further provide evidence that p44/42 MAPK signalling is involved in mediating the adipokine effects, i.e. proliferation.

Not only after $48 \mathrm{~h}$ (Will et al. 2012), but already after $4 \mathrm{~h}$, adiponectin treatment of porcine myoblasts resulted in a significant decrease of DNA synthesis rate, which may indicate a delayed onset of proliferation. This is suggested to result from the inhibition of bFGF, which was identified to be the reason for attenuated DNA synthesis of porcine myoblasts after adiponectin long-term treatment (Will et al. 2012). The decrease in the specific activation of p44/42 MAPK after 15- and 30-min exposure to adiponectin, observed in the present study, could also result from an adipokine-mediated attenuation of bFGF action, as p44/42 MAPK is activated by extracellular stimuli like growth factors or hormones (Cobb \& Goldsmith 1995). As p44/42 MAPK is an important mediator of cell proliferation, the decline in its specific activation, observed in GF-SFM, may result in a reduced DNA synthesis rate. Further studies on porcine skeletal muscle cells with respect to receptor ligand binding under GF-SFM culture conditions may clarify the adiponectin effects in more detail. Whether the inhibition of p44/42 MAPK in myoblasts by adiponectin is of biological relevance and results in changes in the activities of down-stream targets under the conditions used in this study needs further 
elucidation. Short-term leptin effects on signalling as well as DNA synthesis rate were similar to those of adiponectin. These effects, however, are considered to be transient, because after long-term treatment with leptin over $24 \mathrm{~h}$ or $48 \mathrm{~h}$, any responses of porcine myoblasts in DNA synthesis rate or DNA content were no longer detectable under identical culture conditions (Will et al. 2012). As the event of proliferation occurs as a consequence of DNA synthesis, a decrease in DNA content might be probably not yet apparent after 4-h treatment. Under low serum conditions, the phosphorylation level of p44/42 MAPK behaved differently in response to the adipokines. There was a transient activation of p44/42 MAPK after $15 \mathrm{~min}$, followed by decreases after 60 and 180 min, which was associated with increases in DNA synthesis rate and cell death (Will et al. 2013).

In the long range, the presence of adiponectin or leptin in the culture medium seemed to improve cell viability of the myoblasts as LDH activity was lower in medium samples taken at 48-h, but not after 10-h and 24-h treatments. However, under GF-SFM conditions, the rate of cell death was very low at each of three time points examined, nearly $30-50 \%$ in comparison to low serum (1\% FBS) conditions (Will et al. 2013). In conclusion, adiponectin and leptin treatment will not enhance the rate of cell death in primary porcine myoblast cultures, if growth factors are present in cell culture medium. In contrast, cell viability was transiently decreased by about $30 \%$ in response to adiponectin or leptin after $24-\mathrm{h}$ treatment under low serum conditions (Will et al. 2013). The different responses of porcine myoblasts to the adipokines in GF-SFM compared to low serum conditions suggest that adipokine actions on muscle cells may be modified by endocrine and paracrine actions.

The phosphorylation levels of AMPK, Akt and mTOR were not changed under leptin or adiponectin treatment of cells for 15 or 30 min in GF-SFM, which might be due to a cell typespecific activation of intracellular signalling pathways by adiponectin and leptin. Although various studies have reported on adiponectin-induced activation of AMPK in muscle cells or muscle tissue, this was only in the context of glucose transport or fatty acid oxidation (Yoon et al. 2006). Several other studies showed an activation of AMPK and Akt after leptin treatment (Maroni et al. 2005, Minokoshi et al. 2002). However, nothing is known about intracellular signalling pathways involved in adipokine-mediated effects on cell proliferation of primary porcine myoblasts. Thus, the animal species, the nature of the cells used, culture conditions or the specific preparations of recombinant adiponectin or leptin may be responsible for the lack of activation of these signalling molecules in our study. The growth medium used in this study was energetically balanced. Therefore, adiponectin and leptin might not lead to regulatory cell responses regarding energy metabolism and any short-term effects may be compensated very fast. Moreover, in contrast to other studies using immortalized cell lines, in this study primary skeletal muscle cells were used, which may exhibit different sensitivity to external signals.

In conclusion, short-term adiponectin or leptin treatments resulted in similar decreases in DNA synthesis rate of porcine skeletal muscle cells when cultured under growth factorsupplemented, serum-free conditions. No negative effects were observed on cell viability within $48 \mathrm{~h}$. Phosphorylation levels of AMPK, mTOR and Akt remained unchanged during incubation of primary myoblasts with adiponectin or leptin over a period of $30 \mathrm{~min}$. However, the phosphorylation levels of extracellular-signal regulated kinases-type MAP kinases (p44/42 MAPK) were at least transiently reduced during the initial period of adiponectin or leptin stimulation of cells. Additional research is needed to clarify the lack of effects of adipokine 
treatment on other key signalling molecules and to identify factors acting as modulators for adipokine action on muscle cell growth.

\section{Acknowledgements}

We thank the International Leibniz Graduate School on Functional Diversity in Farm Animals for financial support. Angela Steinborn and Anne Berndt are gratefully acknowledged for excellent technical assistance.

\section{References}

Arita Y, Kihara S, Ouchi N, Maeda K, Kuriyama H, Okamoto Y, Kumada M, Hotta K, Nishida M, Takahashi M, Nakamura T, Shimomura I, Muraguchi M, Ohmoto Y, Funahashi T, Matsuzawa Y (2002) Adipocyte-Derived Plasma Protein Adiponectin Acts as a Platelet-Derived Growth Factor-BB-Binding Protein and Regulates Growth Factor-Induced Common Postreceptor Signal in Vascular Smooth Muscle Cell. Circulation 105, 2893-2898

Bonen A (2010) Muscles as molecular and metabolic machines. Am J Physiol Endocrinol Metab 299, E143-E144

Bonnet M, Cassar-Malek I, Chilliard Y, Picard B (2010) Ontogenesis of muscle and adipose tissues and their interactions in ruminants and other species. Animal 4 (Special Issue), 1093-1109

Brochu-Gaudreau K, Rehfeldt C, Blouin R, Bordignon V, Murphy BD, Palin MF (2010) Adiponectin action from head to toe. Endocrine 37, 11-32

Carbó N, Ribas V, Busquets S, Alvarez B, López-Soriano FJ, Argilés JM (2000) Short-term effects of leptin on skeletal muscle protein metabolism in the rat. J Nutr Biochem 11, 431-435

Cobb MH, Goldsmith EJ (1995) How MAP Kinases Are Regulated. J Biol Chem 270, 14843-14846

Doumit ME, Cook DR, Merkel RA (1996) Testosterone Up-Regulates Androgen Receptors and Decreases Differentiation of Porcine Myogenic Satellite Cells in Vitro. Endocrinology 137, 1385-1394

Fiaschi T, Cirelli D, Comito G, Gelmini S, Ramponi G, Serio M, Chiarugi P (2009) Globular adiponectin induces differentiation and fusion of skeletal muscle cells. Cell Res 19, 584-597

Fiaschi T, Tedesco FS, Giannoni E, Diaz-Manera J, Parri M, Cossu G, Chiarugi P (2010) Globular Adiponectin as a Complete Mesoangioblast Regulator: Role in Proliferation, Survival, Motility, and Skeletal Muscle Differentiation. Mol Biol Cell 21, 848-859

Frühbeck G (2008) Overview of Adipose Tissue and Its Role in Obesity and Metabolic Disorders. In: Yang K (ed.) Adipose Tissue Protocols. 2nd ed., Methods in Molecular Biology 456, Totowa, NJ, USA, 1-22

Gimeno RE, Klaman LD (2005) Adipose tissue as an active endocrine organ recent advances. Curr Opin Pharmacol 5, 122-128

Hauner H (2005) Secretory factors from human adipose tissue and their functional role. Proc Nutr Soc 64, 163-169

Lamošová D, Zeman M (2001) Effect of Leptin and Insulin on Chick Embryonic Muscle Cells and Hepatocytes. Physiol Res 50, 183-189

Ledoux S, Campos DB, Lopes FL, Dobias-Goff M, Palin MF, Murphy BD (2006) Adiponectin Induces Periovulatory Changes in Ovarian Follicular Cells. Endocrinology 147, 5178-5186

Lee MH, Klein RL, El-Shewy HM, Luttrell DK, Luttrell LM (2008) The Adiponectin Receptors AdipoR1 and AdipoR2 Activate ERK1/2 through a Src/Ras-Dependent Pathway and Stimulate Cell Growth. Biochemistry 47, 11682-11692

Löhrke B, Viergutz T, Shahi SK, Pöhland R, Wollenhaupt K, Goldammer T, Walzel H, Kanitz W (1998) Detection and functional characterisation of the transcription factor peroxisome proliferator-activated receptor gamma in lutein cells. J Endocrinol 159, 429-439

Maroni P, Bendinelli P, Piccoletti R (2005) Intracellular signal transduction pathways induced by leptin in C2C12 cells. Cell Biol Int 29, 542-550 
Maroni P, Citterio L, Piccoletti R, Bendinelli P (2009) Sam68 and ERKs regulate leptin-induced expression of OB-Rb mRNA in C2C12 myotubes. Mol Cell Endocrinol 309, 26-31

Mau M, Kalbe C, Viergutz T, Nürnberg G, Rehfeldt C (2008b) Effects of Dietary Isoflavones on Proliferation and DNA Integrity of Myoblasts Derived from Newborn Piglets. Pediatr Res 63, 39-45

Mau M, Oksbjerg N, Rehfeldt C (2008a) Establishment and conditions for growth and differentiation of a myoblast cell line derived from the semimembranosus muscle of newborn piglets. In Vitro Cell Dev Biol Animal 44, 1-5

Miner JL (2004) The adipocyte as an endocrine cell. J Anim Sci 82, 935-941

Minokoshi Y, Kim YB, Peroni OD, Fryer LGD, Müller C, Carling D, Kahn BB (2002) Leptin stimulates fatty-acid oxidation by activating AMP-activated protein kinase. Nature 415, 339-343

Moon HS, Dalamaga M, Kim SY, Polyzos SA, Hamnvik OP, Magkos F, Paruthi J, Mantzoros CS (2013) Leptin's Role in Lipodystrophic and Nonlipodystrophic Insulin-Resistant and Diabetic Individuals. Endocr Rev 34, 377-412

Mullen KL, Pritchard J, Ritchie I, Snook LA, Chabowski A, Bonen A, Wright D, Dyck DJ (2009) Adiponectin resistance precedes the accumulation of skeletal muscle lipids and insulin resistance in high-fat-fed rats. Am J Physiol Regul Integr Comp Physiol 296, R243-R251

Peterson GL (1977) A simplification of the protein assay method of Lowry et al. which is more generally applicable. Anal Biochem 83, 346-356

Ramsay TG (2003) Porcine leptin inhibits protein breakdown and stimulates fatty acid oxidation in $\mathrm{C} 2 \mathrm{C} 12$ myotubes. J Anim Sci 81, 3046-3051

Rehfeldt C, Renne U, Sawitzky M, Binder G, Hoeflich A (2010) Increased fat mass, decreased myofiber size, and a shift to glycolytic muscle metabolism in adolescent male transgenic mice overexpressing IGFBP-2. Am J Physiol Endocrinol Metab 299, E287-E298

Rehfeldt C, Walther K (1997) A Combined Assay for DNA, Protein, and Incorporated [3H] Label in Cultured Muscle Cells. Anal Biochem 251, 294-297

Tomas E, Tsao TS, Saha AK, Murrey HE, Zhang CC, Itani SI, Lodish HF, Ruderman NB (2002) Enhanced muscle fat oxidation and glucose transport by ACRP30 globular domain: Acetyl-CoA carboxylase inhibition and AMPactivated protein kinase activation. Proc Natl Acad Sci USA 99, 16309-16313

Tsao TS, Tomas E, Murrey HE, Hug C, Lee DH, Ruderman NB, Heuser JE, Lodish HF (2003) Role of Disulfide Bonds in Acrp30/Adiponectin Structure and Signaling Specificity: Different oligomers activate different signal transduction pathways. J Biol Chem 278, 50810-50817

Wang Y, Lam KS, Xu JY, Lu G, Xu LY, Cooper GJS, Xu A (2005) Adiponectin Inhibits Cell Proliferation by Interacting with Several Growth Factors in an Oligomerization-dependent Manner. J Biol Chem 280, 18341-18347

Wang C, Mao X, Wang L, Liu M, Wetzel MD, Guan KL, Dong LQ, Liu F (2007) Adiponectin Sensitizes Insulin Signaling by Reducing p70 S6 Kinase-mediated Serine Phosphorylation of IRS-1. J Biol Chem 282, 7991-7996

Will K, Kalbe C, Kuzinski J, Lösel D, Viergutz T, Palin MF, Rehfeldt C (2012) Effects of leptin and adiponectin on proliferation and protein metabolism of porcine myoblasts. Histochem Cell Biol 138, 271-287

Will K, Kuzinski J, Kalbe C, Palin MF, Rehfeldt C (2013) Effects of leptin and adiponectin on the growth of porcine myoblasts are associated with changes in p44/42 MAPK signaling. Domest Anim Endocrin 45, 196-205

Yamauchi T, Kamon J, Waki H, Terauchi Y, Kubota N, Hara K, Mori Y, Ide T, Murakami K, Tsuboyama-Kasaoka N, Ezaki O, Akanuma Y, Gavrilova O, Vinson C, Reitman ML, Kagechika H, Shudo K, Yoda M, Nakano Y, Tobe K, Nagai R, Kimura S, Tomita M, Froguel P, Kadowaki T (2001) The fat-derived hormone adiponectin reverses insulin resistance associated with both lipoatrophy and obesity. Nat Med 7, 941-946

Yoon MJ, Lee GY, Chung JJ, Ahn YH, Hong SH, Kim JB (2006) Adiponectin Increases Fatty Acid Oxidation in Skeletal Muscle Cells by Sequential Activation of AMP-Activated Protein Kinase, p38 Mitogen-Activated Protein Kinase, and Peroxisome Proliferator-Activated Receptor a. Diabetes 55, 2562-2570

Yu T, Luo G, Zhang L, Wu J, Zhang H, Yang G (2008) Leptin Promotes Proliferation and Inhibits Differentiation in Porcine Skeletal Myoblasts. Biosci Biotechnol Biochem 72, 13-21 